\title{
Nationalism and sexuality: middle-class morality and sexual norms in Modern Europe
}

by George L. Mosse, Madison, Wi, USA, the University of Wisconsin Press, 2020, xv+230pp., \$32 (paperback), ISBN 978-0299329648

\section{Cemre Aydoğan}

To cite this article: Cemre Aydoğan (2021): Nationalism and sexuality: middle-class morality and sexual norms in Modern Europe, Ethnic and Racial Studies, DOI: 10.1080/01419870.2021.1948089

To link to this article: https://doi.org/10.1080/01419870.2021.1948089

曲 Published online: 14 Jul 2021.

Submit your article to this journal ๔

Џ Article views: 20

Q View related articles $₫$

View Crossmark data $\nearrow$ 


\section{BOOK REVIEW}

Nationalism and sexuality: middle-class morality and sexual norms in Modern Europe, by George L. Mosse, Madison, Wi, USA, the University of Wisconsin Press, 2020, xv+230pp., \$32 (paperback), ISBN 978-0299329648

George L. Mosse's book, Nationalism and Sexuality: Middle-Class Morality and Sexual Norms in Modern Europe, firstly published in 1985, is still considered a classic, and this last edition starts with "a critical introduction" by Mary Louise Roberts (ix). This critical introduction emphasizes the main findings of the book and why this book is still important in the nationalism studies. Mosse's research demonstrates intrinsic relations between nationalism and the notion of respectability. Mosse defines respectability as "bourgeois set of norms defining proper behavior for men and women" (ix); therefore, demonstration of hegemony of the nationalist ideas and doctrines over human bodies in the modern Europe is the main aim of the book.

Mosse mainly focuses on arguments of the late eighteenth century and nineteenth century's European psychologists, artists, philosophers, poets, writers and re-interpreted religious texts in order to discuss and depict the intellectual atmosphere in modern Europe. He also applies to the texts of Enlightenment writers. The main region he worked on is Western Europe, especially with a focus on Germany, formerly Prussia and England. He centralizes "a bourgeois movement" (4) and embodiment process of the norms of bourgeoises among all segments and classes of societies in the nineteenth century's Europe. Those norms, also called as respectability, are re-invented according to the nationalist ideas, and consolidated gender binary and hierarchy. In other words, those norms show how "nationalism helped control of sexuality" (11). While manliness was accepted as the real source of power, and men had to think of their nation-states first, womanliness was accepted "as a national symbol, and woman was the guardian of the traditional order. Always, women exemplified virtue" (18). Thus, the borders between the two gender became more palpable through the spread of the norms of the bourgeoises. The author also discusses homosexuality in the nineteenth century, and he argues that homosexuals were concrete examples of national anomalies because they did not fit in the form of bourgeois-style description of gender identities. Effeminate was a menace for European societies because feminine men did not have a place in the bourgeois ethic. The author also shows the certain relation between effeminate and national conspiracies. He stated that "Jews as a group were said to exhibit female traits, just as homosexuals were generally considered effeminate" (35) especially during the early the twentieth century, in Germany. Thus, homosexuals and ethno-religious minorities, such as Jews, became the legitimate internal others of modern Europe through the norms of bourgeoises, then among other classes. On the other side, English 
nationalism when compared to that in Germany, focused on body politics less, and had less sharpened gender identities. This makes the reader more curious about the framework of the bourgeois ethic, or respectability, in Germany.

The author connects those findings with the construction of the Nazi ideology in Germany after the First World War. This time manliness gains more importance in the Nazi ideology, even the body of men. He discusses the perception of man bodies in the 1930s' Germany, and argues that every reference about socially constructed meanings of manliness became sacred and necessary in German nationalism. Even friendship was also "a natural union among men" that was vital for the sake of group identity. Construction of this strict group identity required to abandon other preferences and identities, in other words, individualism was depicted as the most harmful concept in the bourgeois ethic that was also a central part of the Nazi ideology. The author also makes a comparison between Nazi Germany and fascist Italy in order to demonstrate the relation between nationalism and sexuality in the fascist regimes. Chapter 7 and 8 analyse racist stereotypes and how they consolidated nationalist arguments and their capacity of influence on strict groupism and sexual norms. Mosse argues that "Italian fascism provided many more outlets for individual creativity than National Socialism and tended to be less strict in matters of manners and morals" (161). This quote demonstrates intense focus on body politics in Nazi Germany and how Nazi Germany suppressed individualism that would reject national and sexual norms of bourgeoises. The author also discusses homoeroticism, and states that "male friendship faced that homoeroticism always close to the surface of nationalism" (62), and indicates how homoeroticism was sinful just from the very beginning of National Socialism in Germany because controlled-sexual relations, in accordance with gender binary, were always one of the first goals of the Nazi ideology, in contrast to other fascist states, like in fascist Italy.

The concluding chapter displays that bourgeois ethic or the notion of respectability was emerged in the nineteenth century, and it was not a sole explanation of the rise of nationalism, then fascism, in Europe. Nationalism served for penetration of respectability in all spheres of life, and their mutual relation helped the rise of fascism in the twentieth century (193). Racial stereotypes became more powerful to isolating ethnic or religious groups than sexual references of the bourgeois ethic, but this does not mean that homosexuals were emancipated in societies. Homosexuals turned into the secondary internal enemies of the European societies, especially German society (192). The author refers to Auschwitz and states that Auschwitz was formerly to persecute Jews and those with Jewish behaviours. Therefore, the othering way of homosexuals in modern Europe was used as a tool to exclude Jews through more deadly ways.

Overall, Mosse's book demonstrates the leading ideas of the eighteenth and nineteenth centuries' Europe on the emergence of a new ethic and its spread all around Europe, especially in Western Europe. Although a comparison between England and Germany, formerly Prussia, offers historical ties between bourgeois ethic and nationalism, then a relation between sexuality and nationalism in different parts of Europe, German experience is the most radical example of the bourgeois ethic and its reflection combining racist doctrines in the twentieth 
century. This is important in order to understand the penetration of nationalism in sexual norms and its accelerator role on fascism.

Cemre Aydoğan Department of History, Anthropology, Religions, and Performing Arts, Sapienza University, Rome, Italy @ cemre.aydogan@uniroma1.it

(c) 2021 Cemre Aydoğan https://doi.org/10.1080/01419870.2021.1948089

(D) Check for updates 